\title{
Effect of Web Opening Location on Fatigue Assessment of H Section Steel Beams
}

\author{
A. A. Elboghdady', M. A. Dabaon ${ }^{1,2}$, N. M. Yossef ${ }^{2}$, Mahmoud H. El-Boghdadi $^{2}$ \\ ${ }^{1}$ Civil Engineering Dept., Faculty of Engineering, Horus University, New Damietta, Egypt \\ ${ }^{2}$ Structural Engineering Dept., Faculty of Engineering, Tanta University, Tanta, Egypt \\ Email: ${ }^{1}$ aamr@horus.edu.eg, ${ }^{2} \mathrm{~m}$ dabaon@yahoo.com, ${ }^{3}$ nashwa abdeltawab@f-eng.tanta.edu.eg, \\ mahmoud.el-boghdadi@f-eng.tanta.edu.eg
}

\begin{abstract}
In the last decades, steel beams with web opening were used extensively as useful structural and architectural elements due to their many advantages. In this research, steel beams with web opening subjected to static loading were modelled using the multi-purpose finite element software ANSYS and the finite element results were compared with previous research. Then, steel beams with a single web opening subjected to fatigue loading were investigated numerically. The effect of changing the location of web opening on the fatigue assessment of $H$ section steel beams with web opening was studied taking normal stress into account. It was clear that, normal stress fatigue life of the steel beams was affected significantly by changing web opening location along the beam span when compared to a beam with solid web while the beam span, opening size and steel section were kept constant. The most convenient location of web opening along the beam span was found to be at mid span.
\end{abstract}

Keywords: Finite Element Study; Web Opening; Opening Location; Fatigue Loading

\section{INTRODUCTION}

Due to their structural, architectural and economic superiority to the solid web beams, steel beams with web openings have been widely used recently. Existence of web opening in steel beams of buildings and bridges can facilitate passage of cables, pipes and other services and these beams have acceptable appearance as well [1]. The only drawback of existence of web opening in steel beams is reducing the beam's structural condition as the ability to withstand external loads is lowered.

Since the last century, Redwood [2] in 1969 studied steel beams with circular web openings that were subjected to static loading. An innovative design method that involves using an equivalent imaginary rectangular opening instead of the original web opening was introduced. Then, Redwood and Cho [3] in 1993 proposed a design method for steel-concrete composite beams with web perforations. Later, Chung et al. [4] in 2001 shed some light on one of the common failure mechanisms of steel beams with web opening which is called the Vierendeel mechanism using a combination of numerical and analytical methods. In the recent decades, steel beams with web openings with different shapes and configurations that were subjected to static loading were studied excessively by many scholars using experimental work [5-11] and numerical studies [12-14] as well. The majority of the previously mentioned investigations indicated that, due to the existence of web opening, four zones of stress concentration were produced around the opening as a result of Vierendeel mechanism.
Fatigue phenomenon is recognized as one of the major causes of failure for steel structures. Kyung et al. [15] examined fatigue behavior of steel plate girders and suggested a restoration method for fatigue cracks. Composite prestressed plate girders were studied by Ryu et al. [16] under the effect of fatigue loading using finite element investigation and experimental work as well.

Since the cyclic loading can result in initiation and propagation of fatigue cracks, steel elements under the effect of cyclic loading were investigated by many researchers. These elements must be designed to withstand seismic loading due to earthquakes [17]. Consequently, some scholars focused on investigating $\mathrm{T}$ shaped steel connections with solid beam web such as Kim et al. [18] who studied the seismic performance of these connections experimentally and Calado [19] who suggested using an analytical model to investigate their behavior. It became clear that with no web opening the plastic section formed close to column face instead of the rest of the beam span.

Moreover, researchers continued studying steel connections subjected to bending moment due to seismic loading conditions having circular web opening in the beam using finite element software and experimental tests as well [20]. During these investigations, it became obvious that, introducing a web opening in the beam caused changing the location of the formed plastic hinge from the column face to the areas close to the web opening. On the other hand, Yang et al. [21] concentrated on studying the behavior of steel frames with circular web opening in the beam subjected to cyclic loading conditions numerically and experimentally. It was concluded that, the web opening helped saving the connection between column and beam from sudden brittle failure of the weld material. According to the previously mentioned investigations, it can be realized that, the scholars gave much attention to studying the behavior of steel beams due to seismic loading but on the other hand, they gave little consideration to fatigue failure.

While the former researchers studied the behavior of steel beams with web openings under the effect of static loading and cyclic loading excessively, they didn't focus on fatigue failure. Therefore, the main concern of this study is to investigate the performance of steel beams with circular web opening under the effect of fatigue loading with the use of numerical analysis. The primary objective of this study is to investigate the performance of steel beams with web opening under the effect of fatigue loading taking into consideration normal stress induced in the steel beams. 


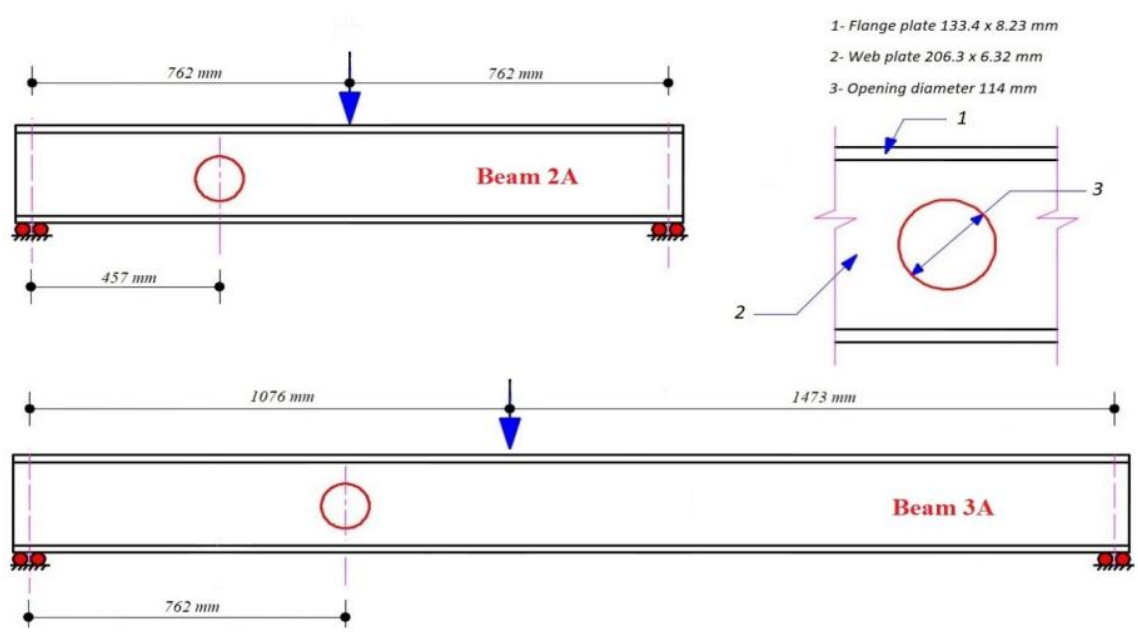

Fig. 1. Details of numerical static loading model (beam 2A \& 3A) [4]

To achieve the research objective, the following approach should be followed: Firstly, creating a numerical model to simulate fatigue performance of steel beams with circular opening in the web. Secondly, the proposed numerical model should be verified and compared to former research including studies of static loading results. At last, conducting a parametric study to investigate the effect of opening location on fatigue life of steel beams with web opening.

\section{NUMERICAL MODEL AND VERIFICATION}

\section{A. Considered Case of Investigation}

The structural case that is taken into consideration herein is a structural beam used in a steel bridge, so it is subjected to moving loads that will cause stress cycles which will lead to fatigue loading. The used beam is supported with hinge from one side and roller from the other side with a single web opening. According to the previous studies, the presence of a web opening in steel beams causes four zones of stress concentration around the opening which is not the case when analyzing beams without web opening. Numerical models from former studies [4] were investigated and reconstructed using ANSYS 17.1 software [22]. After that, the numerical models were verified against former research results. Then, new models were constructed to simulate steel beams with web opening subjected to fatigue loading.

\section{B. Simulation and Verification of Numerical Models of} Beams with Web Opening Subjected to Static Loading

Steel beams with web opening under the effect of static loading were studied by Chung et al. in 2001 [4] using numerical models and analytical solution as well. Their results were verified using former experimental data from literature. Details, shape and dimensions of the tested beams (2A and $3 \mathrm{~A}$ ) are demonstrated in Fig. 1. Former scholars used solid elements in numerical studies to investigate steel beams [23] and frames as well [24]. Solid elements 186 and 187 were used to model the tested beams using ANSYS 17.1 finite element software. Both solid elements (186 that had 20 nodes and 187 that had 10 nodes) had three degrees of freedom per node. These elements are appropriate for plastic analysis and allows for high deflections.

Based on guide runs, element size of $20 \mathrm{~mm}$ was selected to minimize the solution time and make sure that the achieved solution accuracy was satisfactory. Shape of meshing and loads are shown in Fig. 2. More than 1500 elements were produced in the vicinity of the web opening. Stress-strain curve with bilinear profile was used to model the nonlinearity of the steel material agreeing with Eurocode 3 part 1-5 [25]. Steel material with isotropic and homogenous properties with modulus of elasticity taken equal to $200 \mathrm{GPa}$ and tangent modulus of $2 \mathrm{GPa}$. In addition, Poisson' ration of 0.3 was used, while yield strength were taken as $352 \mathrm{MPa}$ and 376 MPa for flanges and web respectively.

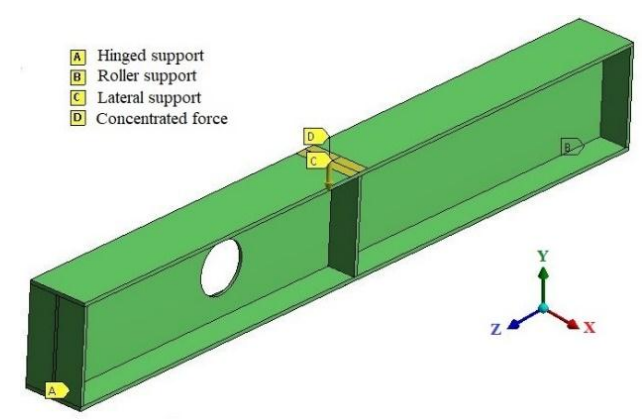

b

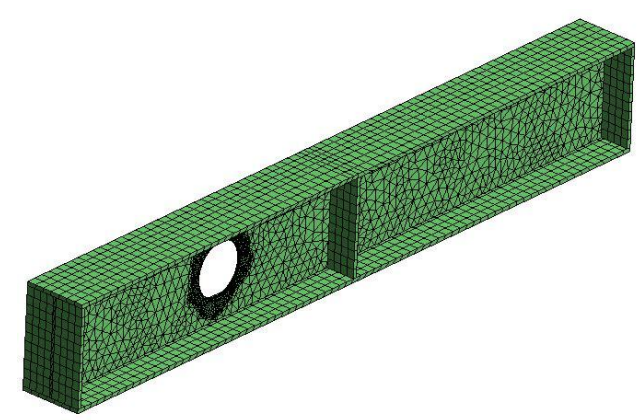

Fig. 2. Static loading finite element model (a: Model and loading shape, b: Meshing shape). 

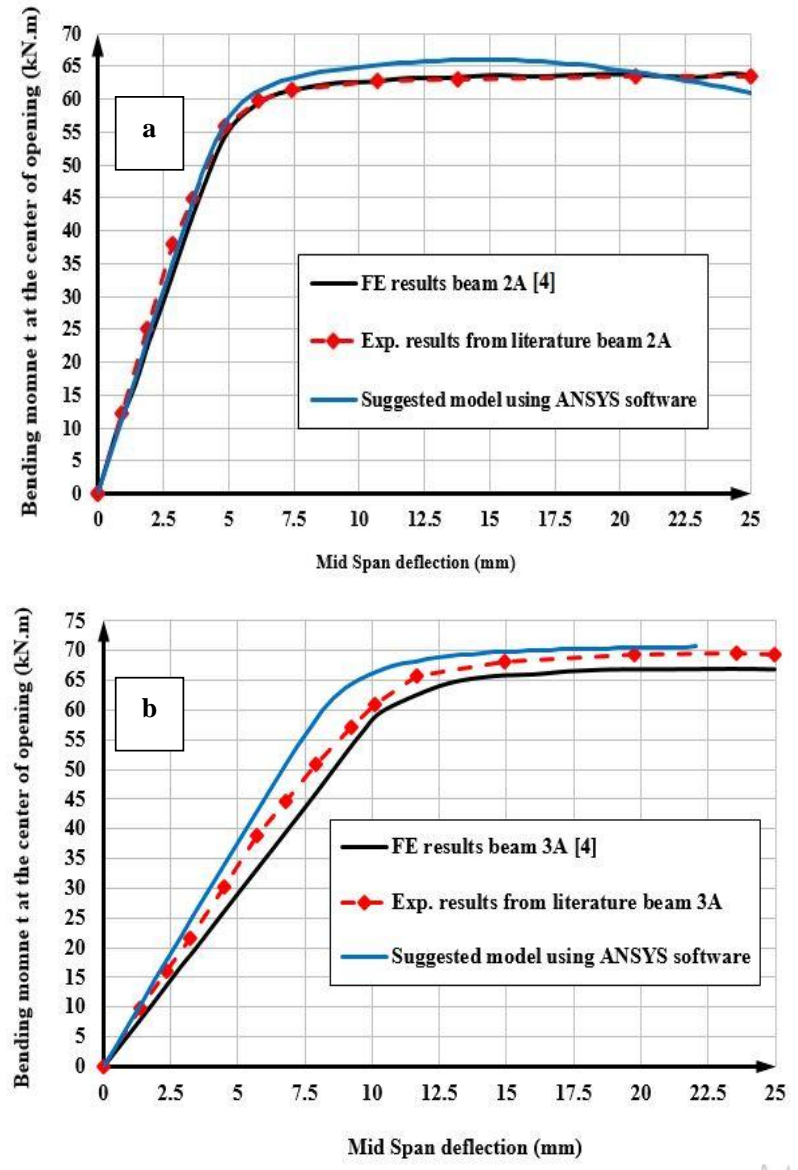

Fig. 3. Comparison between Moment-deflection curves for tested beams $(\mathrm{a} ; 2 \mathrm{~A}, \mathrm{~b} ; 3 \mathrm{~A})$

Comparison between the proposed model, numerical results and the experimental test data from the literature is shown in Table 1. Newton-Raphson technique was used and large displacement for the finite element model was allowed.

Boundary conditions were modelled according to Table 2 with nodes of the bottom flange acting as hinged support on the left edge and roller support on the right edge, while the upper flange point that is located at mid span was acting as lateral support to minimize the unsupported length of the upper compression flange and to make sure that the beam won't suffer lateral torsional buckling during vertical loading.

The beam was loaded at the upper flange point at mid span with a vertical downward concentrated force as shown in Fig. 2. Taking geometric nonlinearity into consideration, initial imperfections were applied. Eigen value buckling analysis was performed in ANSYS software [22] to find the most probable buckling shape. Then, the values displacements and stresses were calculated and transferred to the numerical model. Buckling mode shape 1 was selected while having a scale factor that is equal to the total depth of the beam section divided by 200 . This value was selected based on Eurocode 3 part 1-5 [25]. Bending moment at the centre of web opening was plotted against mid span deflection of the tested beams (2A and $3 \mathrm{~A}$ ) in Fig. 3. The results of the proposed numerical models were compared to results obtained by Chung, et al. in $2001[4]$ and the experimental results from literature.
TABLE I

VERIFICATION AGAINST NUMERICAL RESULTS AND EXPERIMENTAL DATA STUDIED BY CHUNG ET AL. IN 2001 [4]

\begin{tabular}{|c|c|c|c|c|c|}
\hline \multirow[t]{2}{*}{$\begin{array}{l}\text { Tested } \\
\text { beam }\end{array}$} & $\begin{array}{c}\text { Ultimat } \\
\text { e } \\
\text { moment } \\
\text { of the } \\
\text { tests }\end{array}$ & $\begin{array}{c}\text { Ultimate } \\
\text { moment } \\
\text { presented } \\
\text { by [4] }\end{array}$ & $\begin{array}{c}\text { Ultimate } \\
\text { moment } \\
\text { of the } \\
\text { proposed } \\
\text { model }\end{array}$ & \multirow[t]{2}{*}{$\mathbf{M}_{\mathbf{u}, \boldsymbol{t}} / \mathbf{M}_{\mathbf{u}, \mathbf{F E}}$} & \multirow[t]{2}{*}{$\begin{array}{r}\mathbf{M}_{\mathbf{u}, \mathbf{n u m} /} \\
\mathbf{M}_{\mathbf{u}, \mathbf{F E}}\end{array}$} \\
\hline & $\begin{array}{c}\mathbf{M}_{\mathrm{u}, \mathrm{t}} \\
{[\mathrm{kN} . \mathrm{m}]}\end{array}$ & $\begin{array}{c}\mathbf{M}_{\mathrm{u}, \mathrm{num}} \\
{[\mathrm{kN} . \mathrm{m}]}\end{array}$ & $\begin{array}{c}\mathrm{M}_{\mathrm{u}, \mathrm{FE}} \\
{[\mathrm{kN} . \mathrm{m}]}\end{array}$ & & \\
\hline $2 \mathrm{~A}$ & 63.7 & 62 & 66 & $96.51 \%$ & $94 \%$ \\
\hline $3 \mathrm{~A}$ & 69 & 66.4 & 70.6 & $98 \%$ & $94 \%$ \\
\hline
\end{tabular}

TABLE 2

BOUNDARY CONDITIONS OF PROPOSED STATIC LOADING FINITE ELEMENT MODEL

\begin{tabular}{|c|c|c|c|}
\hline Support & $\mathbf{U x}$ & $\mathbf{U y}$ & $\mathbf{U z}$ \\
\hline Mid span point & 1 & 0 & 0 \\
\hline Hinge & 1 & 1 & 1 \\
\hline Roller & 1 & 1 & 0 \\
\hline 1=prevented & \multicolumn{3}{|c}{ permitted }
\end{tabular}

From Fig. 3, it can be deduced that, the proposed numerical model can simulate the behaviour of the tested beams precisely with the same failure mode (Vierendeel mechanism) and almost the same bending moment at the centre of web opening at failure with acceptable accuracy against test results).

\section{Simulation of Steel Beams with Web Opening Subjected to Fatigue Loading.}

The current suggested numerical model was created to simulate common steel structures such as floor beams in buildings and stringer beams in steel bridges. The suggested model is composed of a simply supported beam with a full span of 6 meters and a hot rolled steel section (HEB400). The model was established using ANSYS 17.1 finite element software [22].

Supports were simulated at the bottom flange as the nodes of the left edge (hinged support) were prevented from moving in all directions (X, Y and $\mathrm{Z}$ directions), while nodes of the right edge were stopped from translation in $\mathrm{X}$ and $\mathrm{Y}$ directions but allowed to move in the direction of the beam span ( $\mathrm{Z}$ direction). Mid span point was supported laterally ( $\mathrm{X}$ direction) to prevent lateral torsional buckling of the compression upper flange of the steel beam. Lateral torsional buckling check was performed to ensure that the actual unsupported length of the compression flange didn't exceed the allowable values mentioned in ECP 2005 [26] for compact sections. The final shape of boundary conditions of the beam are shown in Fig. 4. High cycle fatigue load was applied to the upper flange. The load was applied as reversed stress cycles with a ratio of -1 between maximum positive and maximum negative stress amplitudes.

The used material for all steel parts was mild steel 37 which was modelled as a homogenous isotropic material with yield and ultimate stresses of $240 \mathrm{~N} / \mathrm{mm}^{2}$ and $360 \mathrm{~N} / \mathrm{mm}^{2}$ respectively according to ECP 2005 [26]. A bilinear stressstrain profile was assumed with young's modulus of $210 \mathrm{GPa}$, tangent modulus of $2.1 \mathrm{GPa}$ and Poisson's ratio of 0.3 . 


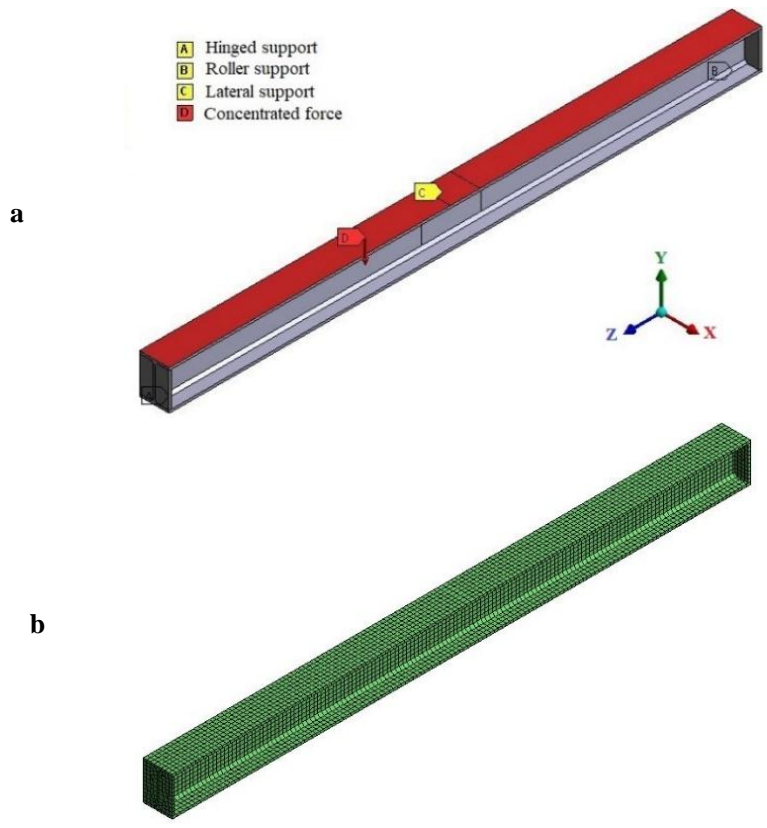

Fig. 4. Model shape, meshing and boundary conditions of the current finite element model

Based on former numerical investigations done by many scholars [27], [28], and according to guide runs, mesh element size of $20 \mathrm{~mm}$ was chosen to model the tested beam. This element size wasn't too large to cause major changes in the obtained results and at the same time it wasn't too small to make the solution run last for too much time. The shape of the produced mesh for the numerical model is shown in Fig. 4. Fatigue resistance and endurance limit were taken according to Eurocode 3 part 1-9 [29].

\section{Verification of Proposed FE Model Against Eurocode3 paert1-9 [29]}

The proposed numerical model was verified against the results available at Eurocode3 [29]. Normal stress fatigue category 160 was used as a reference value for the solid web beam with no web opening subjected to fatigue loading. The proposed FE model was proven accurate in simulating steel beams subjected to fatigue loading as shown in Fig. 6.

\section{E. Parametric Investigation}

Steel beams with one circular opening in the web were tested under the effect of fatigue loading. In this section, the effect of variation of web opening location on fatigue life was examined considering the induced normal stress in the tested beam, while the total span of the beam (S), beam's section, type of loading and web opening depth of $75 \%$ of the beam total section height $\left(\mathrm{d}_{\text {total }}\right)$ weren't changed. The investigated location parameter $(\Phi)$ and schematic of the model are shown in Fig. 5 and explained in eqs. 1 and 2.

$$
\begin{aligned}
& \mathrm{d}=\mathrm{d}_{\text {total }}-4 \mathrm{~s}_{\mathrm{f}} \\
& \Phi=\mathrm{L} / \mathrm{S}
\end{aligned}
$$

Where $\mathrm{S}$ symbolises total beam span, $\mathrm{L}$ represents distance between centre of circular web opening and left side of the tested beam, $d_{\text {total }}$ is the total height of beam section, $d$ is depth of the beam web, $\mathrm{s}_{\mathrm{f}}$ stands for flange thickness and $(\Phi)$ represents location parameter.

Six numerical models were erected containing a solid web beam and five other models with various values of web opening location parameter $(\Phi=0.05,0.1,0.2,0.25$ and 0.5$)$ as clarified in Fig. 5.
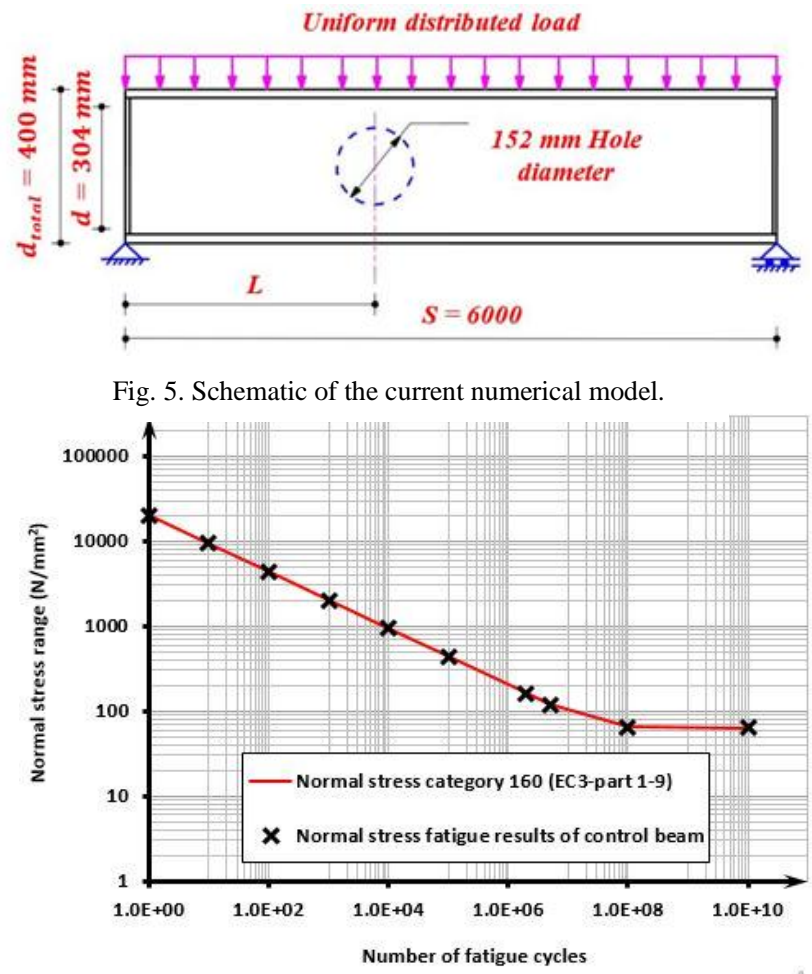

Fig. 6 Validation of proposed FE model against Eurocode3 part 1-9

To fully understand how changing the value of opening location $(\Phi)$ affects the fatigue life of the tested beams with opening in the web, applied load was plotted against number of loading cycles as illustrated in Fig. 7 with load on the vertical axis and number of loading cycles on the horizontal axis using logarithmic scale while the opening size was kept constant at $75 \%$ of the web height for all tested beams.

As stated by Eurocode 3 part 1-9 [29] and the Egyptian code ECP 205 [26], the life of any steel part is considered infinite if it endures more than 2 million loading cycles. Hence it was convenient to calculate the applied load that would cause a fatigue life of 2 million cycles of each tested beam $\left(\mathrm{P}_{2 \text {-model }}\right)$ including the solid beam $\left(\mathrm{P}_{2 \text {-solid }}\right)$. Then, the ratio between the load that would cause a fatigue life of 2 million loading cycles for each numerical model $\left(\mathrm{P}_{2 \text {-model }}\right)$ and the load that would cause a fatigue life of 2 million cycles for the solid beam $\left(\mathrm{P}_{2 \text {-solid }}\right)$ is calculated. This ratio is referred to as fatigue loading ratio (FLR) as illustrated in eq. 3 and Fig. 8.

$$
\mathrm{FLR}=\mathrm{P}_{2 \text {-model }} / \mathrm{P}_{2 \text {-solid }}
$$

Figure 8 indicates that, the location parameters had a major impact on the fatigue life of steel beams with web opening. Increasing the value opening parameter caused a significant rise in the load that the specimen can endure before failure due to fatigue. In addition, it can be deduced from Fig. 8 that, when the location parameter was raised from 0.05 to 0.5 (the 
opening distance from the left support is increased), the fatigue loading ratio (FLR) jumped from $47 \%$ to $87 \%$ which indicates a major improvement in the fatigue resistance of the tested models as demonstrated in Fig. 9.

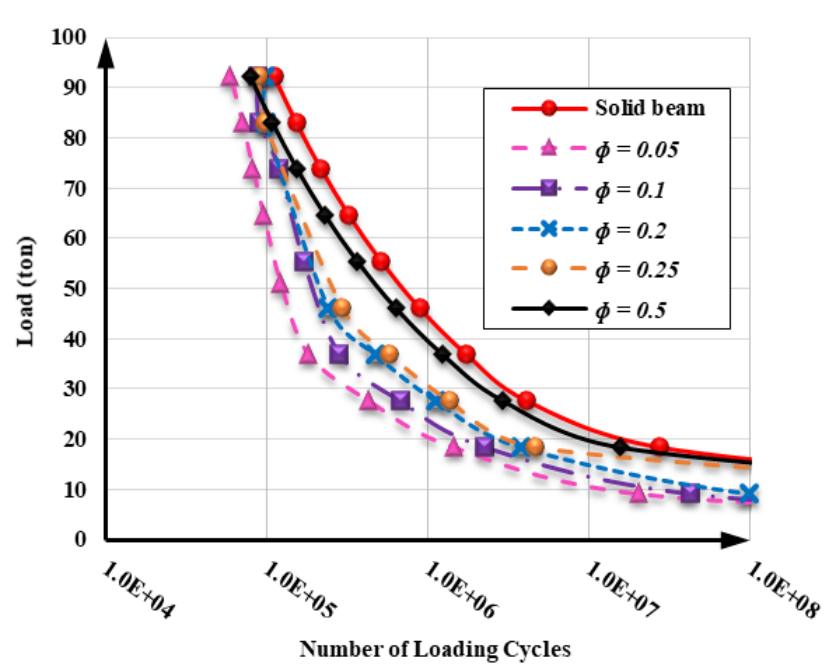

Fig. 7. Effect of location parameter (\$) on load versus number of cycles curves for tested beams.

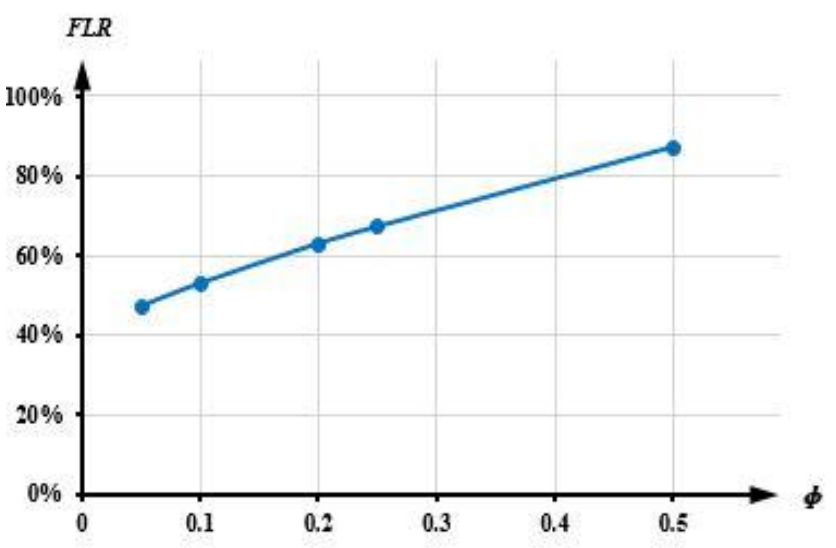

Fig. 8. Effect of location parameter ( $\left.{ }^{\Phi}\right)$ on fatigue load ratio $(F L R)$ of tested beams.

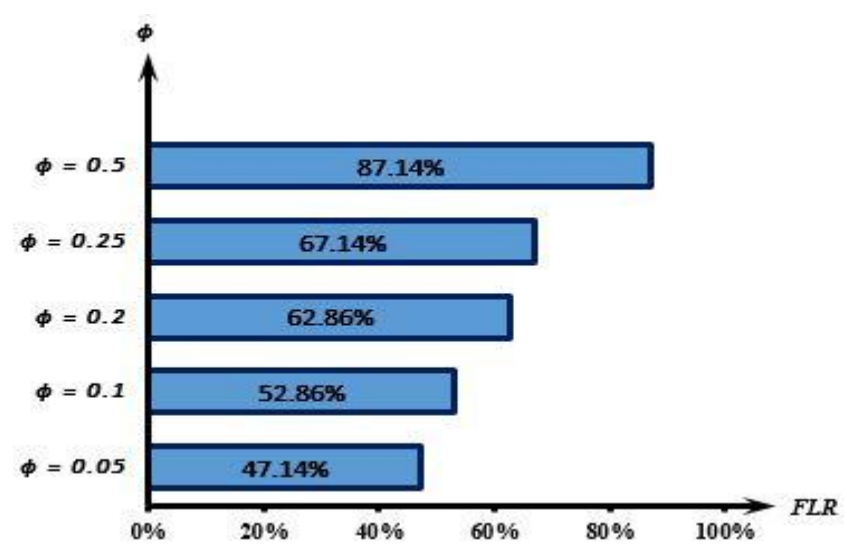

Fig. 9. Fatigue load ratio (FLR) of tested beams.

\section{CONCLUSIONS AND RECOMMENDATIONS}

According to understanding of behaviour of steel beams with web opening under the effect of static loading and the validation of the proposed static model against previous research numerical data [4] and experimental data from literature, a new numerical model was established to study the behaviour of steel beams with a single circular opening in the web and subjected to fatigue loading. The new numerical model was used to conduct a parametric investigation to study the effect of opening location on fatigue life of the tested beams. Based on the parametric investigation, some important deductions were attained.

It was deduced that, increasing the value of opening location parameter $(\Phi)$ contributed in improving the fatigue resistance of the tested beams while the opening size was constant as it caused a major increase in number of loading cycles that the beam endured before fatigue failure. Moreover, positioning the web opening in the middle of span is considered to be safer when compared to the condition of positioning the web opening close to support.

\section{REFERENCES}

[1] N. D. Lagaros, L. D. Psarras, M. Papadrakakis, and G. Panagiotou, "Optimum design of steel structures with web openings," Eng. Struct., vol. 30, no. 9, pp. 2528-2537, 2008, doi: 10.1016/j.engstruct.2008.02.002.

[2] R. G. Redwood, "The strength of steel beams with unreinforced web holes," Civ. Eng. public Work. Rev., vol. 64, no. 755, pp. 559-562, 1969.

[3] R. Redwood and S. H. Cho, "Design of steel and composite beams with web openings," J. Constr. Steel Res., vol. 25, no. 1-2, pp. 23-41, 1993 , doi: 10.1016/0143-974X(93)90050-3

[4] K. F. Chung, T. C. H. Liu, and A. C. H. Ko, "Investigation on vierendeel mechanism in steel beams with circular web openings," J. Constr. Steel Res., vol. 57, no. 5, pp. 467-490, 2001, doi: 10.1016/S0143-974X(00)00035-3.

[5] P. Separa and K. G. Berplat, "Partially Connected Steel-Concrete Composite Plate Girders," vol. 23, pp. 1-10, 2011.

[6] A. Elkady and D. G. Lignos, "Cyclic behavior of deep slender wideflange steel beam-columns under combined lateral drift and axial load," NCEE 2014 - 10th U.S. Natl. Conf. Earthq. Eng. Front. Earthq. Eng., 2014, doi: 10.4231/D3F18SF97.

[7] M. Bosco and L. Tirca, "Numerical simulation of steel I-shaped beams using a fiber-based damage accumulation model," J. Constr. Steel Res., vol. 133, pp. 241-255, 2017, doi: 10.1016/j.jcsr.2017.02.020.

[8] P. Wang, X. Wang, and N. Ma, "Vertical shear buckling capacity of web-posts in castellated steel beams with fillet corner hexagonal web openings," Eng. Struct., vol. 75, pp. 315-326, 2014, doi: 10.1016/j.engstruct.2014.06.019.

[9] K. D. Tsavdaridis and C. D'Mello, "Web buckling study of the behaviour and strength of perforated steel beams with different novel web opening shapes," J. Constr. Steel Res., vol. 67, no. 10, pp. 16051620, 2011, doi: 10.1016/j.jcsr.2011.04.004.

[10] S. G. Morkhade and L. M. Gupta, "Ultimate load behaviour of steel beams with web openings," Aust. J. Struct. Eng., vol. 20, no. 2, pp. 124-133, 2019, doi: 10.1080/13287982.2019.1607448.

[11] K. D. Tsavdaridis and C. D Mello, "FE MODELLING TECHNIQUES FOR COMPLEX WEB-POST BUCKLING RESPONSE OF PERFORATED STEEL BEAMS WITH CLOSELY SPACED WEB OPENINGS OF VARIOUS SHAPES," 6th Eur. Conf. Steel Compos. Struct., vol. 100, no. September 2011, pp. 1851-1856, 2011.

[12] F. Rodrigues, P. C. G. S. Da Vellasco, L. R. O. De Lima, and S. A. L. De Andrade, "Finite element modelling of steel beams with web openings," Engineering, vol. 6, no. 13, pp. 886-913, 2014, doi: 10.4236/eng.2014.613082

[13] N. E. Shanmugam, V. T. Lian, and V. Thevendran, "Finite element modelling of plate girders with web openings," Thin-Walled Struct., vol. 40, no. 5, pp. 443-464, 2002, doi: 10.1016/S0263-8231(02)000083.

[14] N. C. Hagen, P. K. Larsen, and A. Aalberg, "Shear capacity of steel plate girders with large web openings, Part I: Modeling and 
simulations," J. Constr. Steel Res., vol. 65, no. 1, pp. 142-150, 2009, doi: 10.1016/j.jcsr.2008.03.014.

[15] K. S. Kyung, J. E. Park, S. S. Jun, and J. G. Kim, "A study of the evaluation of fatigue crack at welded joint for steel plate girder," Procedia Eng., vol. 14, pp. 1543-1548, 2011, doi: 10.1016/j.proeng.2011.07.194.

[16] H. K. Ryu, Y. J. Kim, and S. P. Chang, "Crack control of a continuous composite two-girder bridge with prefabricated slabs under static and fatigue loads,” Eng. Struct., vol. 29, no. 6, pp. 851-864, 2007, doi: 10.1016/j.engstruct.2006.06.021.

[17] E. Paul Popov, T. S. Yang, and S. P. Chang, "Design of steel MRF connections before and after 1994 Northridge earthquake," Eng. Struct., vol. 20, no. 12, pp. 1030-1038, 1998, doi: 10.1016/S01410296(97)00200-9.

[18] S. Y. Kim, K. J. Shin, S. H. Lee, and H. Du Lee, "Experimental investigation of beam-to-column connection with SHN490 steel under cyclic loading,” Int. J. Steel Struct., vol. 16, no. 4, pp. 1299-1307, 2016, doi: 10.1007/s13296-016-0092-x.

[19] L. Calado, "Non-linear cyclic model of top and seat with web angle for steel beam-to-column conections," Eng. Struct., vol. 25, no. 9, pp. 1189-1197, 2003, doi: 10.1016/S0141-0296(03)00067-1.

[20] X. Zhang, S. Zheng, and X. Zhao, "Seismic performance of steel beamto-column moment connections with different structural forms," J. Constr. Steel Res., vol. 158, pp. 130-142, 2019, doi: 10.1016/j.jcsr.2019.03.028.

[21] Q. Yang, B. Li, and N. Yang, "Aseismic behaviors of steel moment resisting frames with opening in beam web," J. Constr. Steel Res., vol. 65, no. 6, pp. 1323-1336, 2009, doi: 10.1016/j.jcsr.2009.01.007.

[22] “ANSYS $®$, Release 17.1, ANSYS, Inc., 2017.”

[23] D. Turnić, N. Marković, and T. Igić, "Stress analysis of steel plate girders subjected to patch loading in elastoplastic domain," Teh. Vjesn., vol. 28, no. 4, pp. 1408-1414, 2021, doi: 10.17559/TV20190416142242.

[24] M. Anitha and K. K. Divya, "Study on Seismic Behavior of Knee Braced Steel Frames," pp. 40-45, 2015.

[25] "CEN, EN 1993-1-5, Eurocode 3. Design of steel structures - Part 1-5, Plated structural elements., 2007."

[26] ECP-205 (LRFD), "Egyptian Code of Practise for Steel Construction." 2008.

[27] M. Davarpanah, H. Ronagh, P. Memarzadeh, and F. Behnamfar, "Cyclic behaviour of elliptical-shaped reduced web section connection," Structures, vol. 24, no. November 2019, pp. 955-973, 2020, doi: $10.1016 /$ j.istruc.2020.02.016.

[28] K. Tsavdaridis and C. D. Mello, "Vierendeel Bending Study of Perforated Steel Beams with Various Novel Web Opening Shapes, through Non-linear Finite Element Analyses," 2012.

[29] "EN 1993-1-9, Eurocode 3: Design of steel structures - Part 1-9, Fatigue, British Standards Institution, London: BSI. , 2005.” 